\title{
KEPEMIMPINAN KEPALA SEKOLAH, LINGKUNGAN KERJA, MOTIVASI BERPRESTASI DAN KINERJA GURU PAUD DI KORWIL BIDANG PENDIDIKAN KECAMATAN BUNGBULANG KAB. GARUT
}

\author{
Gun Gun Supyan Anwar' ${ }^{1}$, Farida Yuliaty ${ }^{2}$, Sri Rochani Mulyani ${ }^{3}$ \\ 1, 2, ${ }^{\text {Universitas Sangga Buana }}$ \\ ${ }^{2}$ korespondensi : fys.2207@gmail.com
}

\begin{abstract}
The purpose of this research is to analize and discover partially and simultaneously the influence of leadership of principal and work environmey to achieve motivation and the implication to preschool teachers performance in Regional Coordinator of Education Department in Sub District Bungbulang, Garut District. The population of the sample is all the preschool teachers in Regional Districts of Education Department Sub Distrcit Bungbulang, Garut District, are 189 people in total. With using slovin formula as the sampling method and using proportional random sampling method, therefore obtained 65 preschool teachers as a sample of this research. This research method is descriptive quantitative and verificative, whereas the analysis uses path analysis.The results of the hypothesis shows that (1) Leadership of principal affects positively and significantly to achieve motivation in preschool, (2) Work environment affects positively and significantly to achieve motivation of preschool teachers, (3) There are a few positive and significant influence of leadership and work environment to a motivation, and (4) The leadership of principal and work environment affect positively and significantly to preschool teachers performance (5) Work environment affects positively and significantly to preschool teachers performance, (6) Motivation affects positively to preschool teachers performance $72,6 \%$ and the rest is affected by other factor that excluded in this research.
\end{abstract}

Keywords : Leadership of Principal, Work Environment, Achieve Motivation, and Preschool Teachers Performance

\begin{abstract}
ABSTRAK
Penelitian ini bertujuan untuk menganalisis dan untuk mengetahui pengaruh kepemimpinan kepala sekolaah baik secara parsial dan simultan, lingkungan dalam kerja terhadap motivasi berprestasi serta implikasinya pada kinerja guru PAUD di Korwil Bidang Pendidikan Kecamatan Bungbulang Kabupaten Garut. Populasi penelitian ini adalah seluruh guru PAUD dengan jumlah populasi guru PAUD di Korwil Bidang Pendidikan Kecamatan Bungbulang Kabupaten Garut, sebanyak 189 orang. Dengan menggunakan rumus slovin sebagai metode pengambilan sampel dan menggunakan metode sampling acak proporsional, sehingga didapatkan 65 guru PAUD yang dijadikan sebagai sampel dalam penelitian ini. Metode penelitian ini merupakan penelitian kuantitatif deskriptif dan verifikatif, sedangkan analisa data menggunakan Analisis Jalur (Path Analysis). Hasil pengujian hipotesis menunjukkan bahwa (1) Kepemimpinan kepala sekolah berpengaruh positif dan signifikan terhadap motivasi berprestasi PAUD, (2) Lingkungan kerja berpengaruh positif dan signifikan terhadap motivasi berprestasi guru PAUD, (3) Terdapat pengaruh positif dan signifikan kepemimpinan dan lingkungan kerja terhadap motivasi. dan (4) Kepemimpinan kepala sekolah berpengaruh positif dan signifikan terhadap kinerja Guru PAUD (5) Lingkungan kerja berpengaruh positif dan signifikan terhadap kinerja (6) Motivasi berpengaruh positif terhadap kinerja guru PAUD sebesar $72,6 \%$, dan sisanya dipengaruhi factor lain diluar penelitian ini.
\end{abstract}

Kata kunci: Kepemimpinan Kepala Sekolah, Lingkungan Kerja, Motivasi Berprestasi dan Kinerja Guru PAUD

\section{PENDAHULUAN}

Cita-cita mencerdaskan kehidupan bangsa sudah menjadi salah satu tujuan negara Indonesia sebagaimana yang terkandung dalam pembukaan UUD 1945. Pemenuhan hak pendidikan yang berkualitas tercermin dari sejauh mana pencapaian partisipasi sekolah setiap warga negara tanpa membedakan jenis kelamin, ras, tempat tinggal, termasuk juga penyandang disabilitas. Hal ini sejalan dengan 
prinsip "No one left behind" dalam SDGs. Tujuan ke-4 SDGs "terjaminnya kualitas pendidikan yang inklusif dan merata serta meningkatkan kesempatan belajar sepanjang hayat untuk semua" dapat tercapai. Indikator partisipasi sekolah tersebut dapat menjadi alat untuk memantau efektivitas program pendidikan dari pemerintah dan melihat capaian target pembangunan pendidikan, termasuk pendidikan anak usia dini (PAUD). [1]

Sesuai dengan tujuan peningkatan sumber daya mnusia adalah melalui peningkatan kualitas dan proses pembelajaran di sekolah, maka diperlukan tenaga kependidkan kepala sekolah dan guru, yang menjadi salah satu factor unruk pencapaian keberhasilan penyelenggaraan kegiata pendidikan tersebut..

Hal yang harus dipenuhi dalam pelaksanaan pendiikan adalah standar kompetensi bagi tenaga pendidik dan tenaga kependidikan. Menurut Undang- Undang Nomor 14 Tahun 2005 tentang Guru dan Dosen pasal 1 ayat 1 menyebutkan bahwa "guru adalah pendidik profesional dengan tugas utama mendidik, mengajar, membimbing, mengarahkan, melatih, menilai, dan mengevaluasi siswa pada jalur pendidikan formal, pendidikan dasar, dan pendidikan menengah". Sebagai komponen yang penting, guru dalam proses pembelajarannya harus memiliki empat kompetensii yang sesuai dengan Peraturan Menteri Pendidikan Nasional Nomor 16 Tahun 2007 mengenai kualifikasi dan kompetensi. Empat kompetensi yang haru dimiliki oleh guru dapat menjadi gambaran mengenai kinerja guru dalam melaksanakan tugasnya. Empat kompetensi yang harus dimiliki guru tersebut adalah kompetensi pedagogik, kompetensi kepribadian, kompetensi profesional, dan kompetensi sosial.

Profesionalisme guru diharapkan mempunyai tingkat kinerja yang tinggi. Menurut Barnawi dan Arifin (2014) tingkat keberhasilan seorang guru, berrati kinerja guru, dalam pelaksanaan tugasnya pendidikan sesuai dengan tanggung jawab berdasarkan standar kerja yang telah ditetapkan untuk mencapai tujuan pendidikan. Berdasarkan survey awal pada pene;itian ini, diperoleh gambaran umum kinerja guru PAUD di Korwil Bidang Pendidikan Kec. Bungbulang Kabupaten Garut terpenuhi cukup baik walaupun belum optimal. Sebagai salah satu faktor yang menentukan tinggi rendahnya mutu pendidikan, penyelenggaraan pendidikan keberhasilannya sangat ditentukan oleh tingkat kesiapan guru dalam mempersiapkan peserta didiknya melalui kegiatan belajar mengajar.

Bilamana semua komponen persekolahan terpenuhi, maka kinerja guru akan menjadi optimal, apakah itu kepala sekolah, guru, staf pegawai, pesuruh maupun siswa saling mendukung. Peningkatan kinerja gurulah yang menjadi titik sentral dalam peningkatan hasil belajar siswa yaitu kualitas Pendidikan

Area kerja ialah Aspek lain yang bisa mempengaruhi kinerja guru. Seluruh suatu yang terletak disekitar para guru yang bisa pengaruhi dirinya dalam melaksanakan tugastugas yang dibebankan secara raga ataupun non raga merupakan area kerja. Area kerja yang kondusif sanggup membuat bahagia serta mendesak tenaga kependidikan dalsm bekerja dan sanggup tingkatkan tanggung jawab buat 
melaksanakan pekerjaan dengan lebih baik mengarah ke arah kenaikan produktivitas. Bersumber pada komentar dari (Mulyasa, 2013), apabila mempunyai mptivasi yang besar, para pegawai( guru) hendak bekerja dengan serius. Guru hendak memperlihatkan atensi, memiliki atensi, serta mau turut dan dalam sesuatu tugas ataupun aktivitas, bila mempunyai motivasi yang positif. Butuh dibangkitkan motivasi kerja untuk guru supaya bisa menciptakan kinerja yang terbaik. Salah satunya merupakan kemauan buat berprestasi. Bagi McClelland dalam Danim(2012) Seorang yang dikira mempunyai motivasi berprestasi, dia hendak melaksanakan serangkaian usaha supaya bisa mengungguli yang yang lain. Inilah kebutuhan buat berprestasi ialah motif yang secara kontras bisa dibedakan dengan kebutuhan lainnya[2]

Berdasarkan permasalahan di atas, maka penelitu dapat merumuskan 1)Bagaimana kondisi kepemimpinan, lingkungan kerja, motivasi berprestasi dan kinerja guru PAUD, 2)

Seberapa besar kepemimpinan kepala sekolsh dan Lingkungan dalam bekerja mempengaruhi terhadap motivasi berprestasi secara simultan ataupun secara parsial, 3) Seberapa besar pengaruh kepemimpinan dan lingkungan kerja secara parsial dan simultan terhadap kinerja guru, 4) Seberapa besar motivasi berprestasi memberikan pengaruh terhadap kinerja guru PAUD di Korwil Bidang Pendidikan Kecamatan Bungbulang Kabupaten Garut?

\section{TINJAUAN PUSTAKA}

\section{Kepemimpinan Kepala Sekolah}

Sebagai suatu organisasi, sekolah dalam perkembangan dan pencapaian tujuan diharuskan senantiasa mengacu kepada pedoman dan arah pengembangan pendidikan. Faktor eksternal lainnya pun akan mempengaruhi kompleksitas produk dunia industri manakala kita memproses barang dengan kualitas tertentu, maka akan keluar barang dengan kualitas tertentu pula. Berbeda dengan proses pendidikan. Manajemen sekolah merupakan komponen yang sangat strategis dalam proses pendidikan. "Manajemen pembelajaran adalah segala usaha pengaturan proses belajar mengajar, dalam rangka tercapainya proses belajar mengajar yang efektif dan efesien" [3].

Menurut DEPDIKNAS (2007) Sebagaimana konsep manajemen sebagai seni dan ilmu demikisn pula dengan manajemen yang mengelola sumber daya pendidikan untuk mewujudkan suasana belajar serta proses pembelajaran dimana mengupayakan agar peserta didik secara aktif mengembangkan potensi diri yang diperlikan dirinya, masyarakat, bangsa dan negara berupa kekuatan spiritual keagamaan, pengendalian diri, kepribadian, kecerdasan, akhlak mulia, serta ketrampilan.

Dijelaskan oleh Mulyasa "kepemimpinan merupakan kegiatan untuk mempengaruhi orang-orang yang diarahkan terhadap pencapaian tujuan organisasi”. Demikian pula, disebutkan oleh Soewadji Lazaruth (2004) "kepemimpinan merupakan kemampuan dan kesiapan seseorang untuk mengarahkan, membimbing, atau mengatur orang lain”. Ruh yang menjadi pusat sumber gerak organisasi untuk mencapai tujuan, demikian pula halnya kepala sekolah dalam 
kepemimpinannya, maka perilakunya dengan menunjukkan rasa bersahabat, dekat, dan penuh pertimbangan terhadap para guru, baik sebagai individu maupun sebagai kelompok harus mampu memberikan dorongan bagi guru dalam peningkatan kinerjanya. (Mulyasa, 2011). Kurniadin dan Machali mengutip Locke (2014) berpendapat bahwa "kepemimpinan pendidikan adalah segenap kegiatan dalam usaha memengaruhi personal di lingkungan pendidikan pada situasi tertentu agar mereka melalui usaha kerja sama, mau bekerja dengan penuh tanggung jawab, dan ikhlas demi tercapainya tujuan pendidikan yang telah ditetapkan".

Dalam satuan pembelajaran, kepala sekolah ialah pemimpin yng memiliki jabatan dan kedudukan berarti dalam melakukan proses pembelajaran. Selaku pengelola serta selaku pimpinan resmi dari sekolah yang dipimpinnya, yang memiliki tanggung jawab buat berhasilnya penyelenggaraan pembelajaran serta penatalaksanaan administrasi sekolah. Kepala sekolah berfungsi selaku pemimpin yang bertugas serta berperan yang berkaitan dengan kemajuan pembelajaran di sekolah yang dipimpinnya.

Memberdayakan guru berarti selaku upaya membangun kinerja guru yang unggul serta produktif ialah kebijakan yang wajib diambil oleh kepala sekolah. Bagi Larry Lashway dalam Mulyasa( 2011) kepemimpinan merupakan menitikberatkan pada collaboration serta empowerment. Selanjtnya, Bagi Conley and Paul Goldman( 1994) dalam Mulyasa( 2011) facilitative leadership selaku" the behaviors that enhance the collective ability of a school to adapt, solve problems, and impove performance." Mempunyai keahlian yang berkaitan dengan pembinaan disiplin pegawai serta memotivasi, wajib dipunyai oleh seseorang kepala sekolah( Sutomo dkk, 2011).

\section{Lingkungan Kerja}

Menurut Alex S Nitisemito (2000), segala sesuatu yang ada disekitar para pekerja yang dapat mempengaruhi dirinya dalam menjalankan tugas-tugasnya merupakan lingkungan kerja. Ditambhakan oleh Agus Ahyari (2002) lingkungan dimana para karyawan tersebut bekerja, itulah lingkungan kerja. Merupakan tempat yang dapat mempengaruhi dirinya dalam melaksanakan tugas-tugas.

a) Keadaan bangunan yang nyaman; b) Peralatan yang mendukung; c) Adanya rehat, tempat istirahat, dan sarana olahraga; d) sarana transportasi; e) tempat yang strategis; f) perasaan aman dari pegawai; dan g) loyalitas baik yang bersifat vertikal dan horizontal, merupakan indkator dari lingkungan kerja.

\section{Motivasi Berprestasi}

Motivasi merupakan pergantian energy dalam diri seorang yang diisyarati dengan timbulnya" rasa" serta terdapatnya tujuan, ialah motivasi( Mc. Donald dalam Sardiman( 2012)). Dengan motivasi, diharapkan seseorang orang ingin bekerja keras serta bersemangat buat menggapai produktivitas kerja yang besar. Oleh sebab seperti itu Motivasi kerja dikira sangat berarti untuk karyawan. "Motivation is the concept that describe the forces acting on employee that initiate and direct behavior"( Gibson et. angkatan laut(AL), 1991). Motivasi 
merupakan sesuatu dorongan baik dari dalam diri seorang ataupun dari luar buat melaksanakan serangkaian usaha guna menggapai tujuan serta penuhi kebutuhannya. Seorang hendak melaksanakan aktvitas tertentu sebab terdapat motivasi yang hendak jadi kekuatan pendorongnya.

Motivasi berprestasi merupakan" kebutuhan yang kokoh buat berprestasi, dorongan buat sukses, serta berkaitan dengan sepanjang mana orang termotivasi buat melakukan tugas".( McClelland dalam Kurniadin serta Machali( 2014). “ Motivasi berprestasi merupakan suatu dorongan dari dalam diri buat menanggulangi seluruh tantangan serta hambatan dalam upaya menggapai tujuan yang sudah diresmikan".( Usman, 2008) Orang yang mempunyai needs of achievement besar ialah orng yang senantiasa mempunyai pola pikir tertentu kala merancang buat melakukan suatu, ialah dengan memikirkan pekerjaan yang dicoba lumayan menantang ataupun tidak. Setelah itu muncullah seorang yang bersedia bertanggung jawab atas konsekuensi berupaya menggapai tujuan, mengambil resiko yang diperhitungkan, mencari data buat mengukur kemajuan, serta merasa puas dengan hasil yang dicapai. Motivasi buat berprestasi merupakan bagian dari teori motivasi. Berkenaan dengan kenaikan kinerja, bagi Kurniadin serta Machali( 2014), terdapat sebagian model motivasi yang bisa digunakan pemimpin sekolah selaku pendekatan kepada guru, antara lain:( 1) Model tradisional, wujud kewirausahaan kepala sekolah. guru buat Melaksanakan pekerjaan yang membosankan itu mengasyikkan;( 2) model ikatan antarmanusia, kepala sekolah menekankan gimana guru bisa dimotivasi dengan mengidentifikasi kebutuhan sosial guru buat tingkatkan kepuasan kerja;( 3) Model personalia ialah kepala sekolah tidak cuma bertugas membagikan penghargaan kepada guru, namun kepala sekolah pula wajib meningkatkan rasa persatuan Bagi Danim( 2012), terdapat sebagian metode yang bisa digunakan pemimpin buat tingkatkan motivasi, dan kepala sekolah bisa melaksanakannya, antara lain:( 1) Respect, ialah kepala sekolah bisa mengklasifikasikan guru bersumber pada kinerja serta pengalaman;(2) Data, yaitu kepala sekolah senantiasa membagikan data tentang aktivitas organisasi, spesialnya tentang sesuatu aktivitas serta penerapannya. Data wajib diberikan dengan metode yang mendidik serta menarik;( 3) sikap, ialah kepala sekolah yang baik hendak mencontoh sikap yang diharapkan dari guru;( 4) Hukuman, spesialnya kepala sekolah wajib menghukum guru yang bersalah secara terpisah dari anggota yang lain. Dikatakan hukuman yang dijatuhkan bisa lebih tingkatkan guru,( 5) perintah, ialah sutradara yang baik secara tidak langsung hendak membagikan perintah. Sutradara berikan perintah semacam mengundang, serta lebih baik mengawali dengan berikan contoh;( 6) Perasaan, ialah interaksi antara kepala sekolah serta guru wajib dicoba dengan perkata yang baik, diiringi dengan rasa persahabatan dan partisipasi yang menentramkan.

\section{Kinerja Guru}

Kinerja guru ialah hasil yang dicapai guru dalam melakukan tugas pendidikan yang diberikan, yang bisa dilihat pada aktivitas 
perencanaan pendidikan, penerapan pendidikan, penerapan evaluasi pendidikan, serta penelusuran hasil evaluasi. Kinerja mengajar pula bisa dimaksud selaku representasi dari kinerja pekerjaan mengajar ataupun hasil yang dicapai guru dalam penerapan tugas teknis serta fungsional pembelajaran pada waktu tertentu. Menimpa standar kinerja guru, Sahertian menarangkan dalam Rusman( 2013) bahwa : Standar kinerja guru berkaitan dengan mutu guru dalam melakukan tugasnya, semacam:(1) kerja orang dengan siswa;(2) persiapan serta perencanaan pendidikan;( 3 ) pemakaian media pendidikan;( 4) mengaitkan siswa dalam pengalaman belajar yang bermacam- macam; serta( 5) tutorial guru aktif. Dalam dunia pembelajaran, mutu guru sangatlah berarti. Salah satunya merupakan mutu kinerja mengajar. Mutu kinerja mengajar diresmikan dalam Orde nomor. 16 Tahun 2007 dari Menteri Pembelajaran Nasional Republik Indonesia tentang Standar Kualifikasi Akademik serta Kompetensi Guru. Disebutkan kalau standar kompetensi mengajar secara totalitas dikembangkan dari 4 kompetensi utama, ialah kompetensi pedagogik, karakter, sosial serta handal. Keempat kompetensi tersebut diintegrasikan ke dalam kinerja guru.

Undang- undang Nomor 14 Tahun 2005 tentang Guru dan Dosen diatur dalam Pasal 1) Ayat 1):“ Guru ialah pendidik profesional yang tugas pokoknya mendidik, membimbing, memusatkan, melatih, mengevaluaasi, dan mengevaluasi partisipan didik pendidikan baik formal maupun non formal, pendidikan tingkatan dasaar dan pendidikan menengah". Guru ialah pendidik profesional yang peranan utamanya mendidik, mengajar, membimbing, memusatkan, melatih, mengevaluasi dan mengevaluasi partisipan didik pada jenjang pendidikan tertentu. Mengajar ialah profesi yang membutuhkan keahlian istimewa. Buat jadi seorang guru, ada persyaratan, sangat utama sebagai guru profesional yang harus memahami pendidikan dan pengajaran dengan berbagai kemampuan yang harus dibesarkan dalam fase pelatihan tertentu.

Guru profesional ialah guru yang dapat melaksanakan tugasnya secara profesional. Buat dapat memperhitungkan seorang guru sebagai seorang profesional, Mengenai ini dapat dilihat dari 2 sudut pandang, ialah dari tingkatan pendidikan dalam kaitannya dengan aktivitasnya sebagai seorang guru. Kedua, kemampuan bahan ajar, pengelolaan kelas dan tugas- tugas lain yang berkaitan dengan siswa. Guru profesional ialah guru yang dapat melaksanakan tugasnya secara profesional. Buat dapat memperhitungkan seorang guru sebagai seorang profesional, Mengenai ini dapat dilihat dari 2 sudut pandang, ialah dari tingkatan pendidikan dalam kaitannya dengan aktivitasnya sebagai seorang guru. Kedua, kemampuan bahan ajar, pengelolaan kelas dan tugas- tugas lain yang berkaitan dengan siswa. Kualitas kinerja mengajar ditetapkan dalam Peraturan no. 16 Kementerian Pendidikan Nasional Republik Indonesia Tahun 2007 tentang Standar Kualifikasi Akademik dan Kompetensi Guru. Peraturan tersebut tingkatkan standar kompetensi guru dalam 4 kompetensi, yakni kompetensi pedagogik, kompetensi kepribadian, kompetensi sosial, dan kompetensi profesional. 


\section{METODE}

Penelitian ini menggunakan metode deskriptif dan verifikatif dengan pendekatan penelitian kuantitatif. Pendekatan deskriptif digunakan untuk mengetahui bagaimana reaksi konsumen terhadap kepemimpinan pemimpin, lingkungan kerja, motivasi berprestasi, dan prestasi. Kinerja Guru PAUD di Korwil Bidang Pendidikan Kecamatan Bungbulang Kabupaten Garut. Sedang pendekatan verifikatif digunakan untuk mengetahui pengaruh Kepemimpinan Kepala Sekolah Dan Lingkungan Kerja Terhadap Motivasi Berprestasi dan Dampaknya Pada Kinerja Guru PAUD di Korwil Bidang Pendidikan Kecamatan Bungbulang Kabupaten Garut.

Populasi serta sampel dapat dipergunakan menjadi sumber data. Jika hasil penelitian digeneralisasi, sampel yang digunakan sebagai sumber data harus representatif, yang dapat dilakukan sampai jumlah tertentu dengan mengambil sampel secara acak dari populasi. (Riduwan, 2014: 37). Berdasarkan Data Pendidikan Dasar (DAPODIK) Direktorat Jenderal Pendidikan tingkat Usia Dini, tingkat Dasar dan tingkat Menengah Kementerian Pendidikan dan Kebudayaan, jumlah populadinya adalah, sebanyak 189 orang. Dari data tersebut, ukuran sampel ditentukan dengan menggunakan rumus Slovin, dalam penelitian ini dengan 65 responden dengan tingkat kesalahan $10 \%$.

Alat penelitian metode angket didasarkan pada indikator-indikator yang dijelaskan dalam tabel operasionalisasi variabel sehingga setiap pertanyaan yang diajukan kepada setiap responden dapat diukur. Data yang diuraikan dalam tabel operasionalisasi variabel kualitatif diubah ke dalam bentuk kuantitatif dengan menggunakan pendekatan analisis statistik. Dalam hal ini penulis menggunakan kuesioner tertutup atau jawabannya sudah ditentukan sebelumnya dan responden tidak menerima alternatif jawaban. Penulis kemudian menerjemahkan indikator keempat variabel tersebut ke dalam rangkaian pertanyaan untuk memperoleh data primer.

Persamaan Struktural:

Substruktur pertama: diagram jalur X1 dan X2 terhadap $\mathrm{Y}$

$\mathrm{Y}=\rho Y X 1 X 1+\rho Y X 2 X 2+\varepsilon 1$

Substruktur kedua: Diagram jalur $\mathrm{Y}$ ke Z

$Z=P z y+\varepsilon 2$

Substruktur ketiga: Diagram jalur X1 dan X2 dalam kaitannya dengan $\mathrm{Z}$ ke $\mathrm{Y}$

$Z=\rho z x 1 . X 1+\rho z x 2 . X 2+p z y$

Pengujian Secara Simultan (Uji-F):

$$
F=\frac{(n-k-1) x R_{Y X_{1} x_{2}}^{2}}{k x\left(1-R_{Y X_{1} X_{2}}^{2}\right)}
$$

Pemgujian Secara Parsial (Uji-T)

$$
t_{i}=\frac{\rho Y X i}{\sqrt{\frac{\left(1-R_{Y\left(X_{1} X_{2}\right.}^{2}\right) x C R_{i i}}{(n-k-1)}}}
$$

\section{HASIL DAN PEMBAHASAN}

Karakteristik responden yang diteliti dikelompokan berdasarkan jenis kelamin, usia, latar belakang pendidikan, dan masa kerja, dengan jumlah guru pria pada Korwil Bidang Pendidikan Kecamatan Bungbulang sebesar $10 \%$ saja dan lebih didominasi oleh guru wanita sebanyak 90\%, sebagian besar berada pada rentang umur 41-50 tahun sebesar $41 \%$ dan diikuti oleh rentang usia 31-40 dan 21-30 
masing masing sebesar $31 \%$ dan $23 \%$ sedangkan usia diatas 50 tahun sebesar 5\%, lulusan S1 dengan persentase $80 \%$ dan sisanya yaitu lulusan SMA sebesar 20\% dan dengan masa kerja telah mengabdi selama kurang lebih 10-15 tahun dengan persentase $48 \%$, lalu diikuti oleh guru dengan masa kerja kurang dari 10 tahun tahun sebesar $31 \%$ dan sisanya dengan masa kerja diatas 15 tahun yaitu sebesar $21 \%$.

Penelitian ini telah melalui uji validitas setiap variable dengan $r$ hitung $>$ rtabel, pada taraf signifikansi sebesar 5\% dan hasil pengujian menunjukan nilai Cronbach's Alpha keempat variabel dalam penelitian ini bernilai > 0,6 sehingga ketiga variabel dinyatakan reliabel.

\section{Analisis Deskripsi}

Analisis deskripsi berdasarkan rekapitulasi kuisioner yang disebarkan kepada responden dihasilkan sebagai berikut:

Tabel 1: Hasil Analisis Deskripsi

\begin{tabular}{|l|l|c|l|l|}
\hline $\begin{array}{c}\text { No. } \\
\text { Var }\end{array}$ & \multicolumn{1}{|c|}{ Nama Variabel } & $\begin{array}{c}\text { Hasil Analisis } \\
\text { Deskripsi }\end{array}$ & $\begin{array}{c}\text { Nilai Indikator } \\
\text { Tertinggi }\end{array}$ & $\begin{array}{l}\text { Nilai Indikator } \\
\text { Terendah }\end{array}$ \\
\hline 1 & $\begin{array}{l}\text { Kepemimpinan kepala } \\
\text { Sekolah }\end{array}$ & baik & $\begin{array}{l}\text { Kedekatan } \\
\text { dengan para guru }\end{array}$ & $\begin{array}{l}\text { Mendorong } \\
\text { kinerja dan } \\
\text { membimbing }\end{array}$ \\
\hline 2 & Lingkungan Kerja & baik & Rasa aman & $\begin{array}{l}\text { Kurannya } \\
\text { fasilitas rehat } \\
\text { dan sarana } \\
\text { transportasi }\end{array}$ \\
\hline 3 & Motivasi Berprestasi & baik & $\begin{array}{l}\text { Memperhitungkan } \\
\text { keberhasilan }\end{array}$ & $\begin{array}{l}\text { berania } \\
\text { mengambil } \\
\text { risiko }\end{array}$ \\
\hline 4 & Kinerja Guru & baik & $\begin{array}{l}\text { Prosedur } \\
\text { penilaian }\end{array}$ & $\begin{array}{l}\text { Pengembangan } \\
\text { bahan ajar dan } \\
\text { kurang dapat } \\
\text { memotivasi } \\
\text { siswa }\end{array}$ \\
\hline
\end{tabular}

Hasil olah penulis,2021

\section{Analisis Verifikatif}

Analisis jalur dilakukan untuk mengetahui pengaruh kepemimpinan dan lingkungan kerja terhadap motivasi dan untuk mengetahui pengaruh kepemimpinan dan lingkungan kerja terhadap kinerja. melalui motivasi. Adapun gambar analisis jalur secara lengkap sebagai berikut :

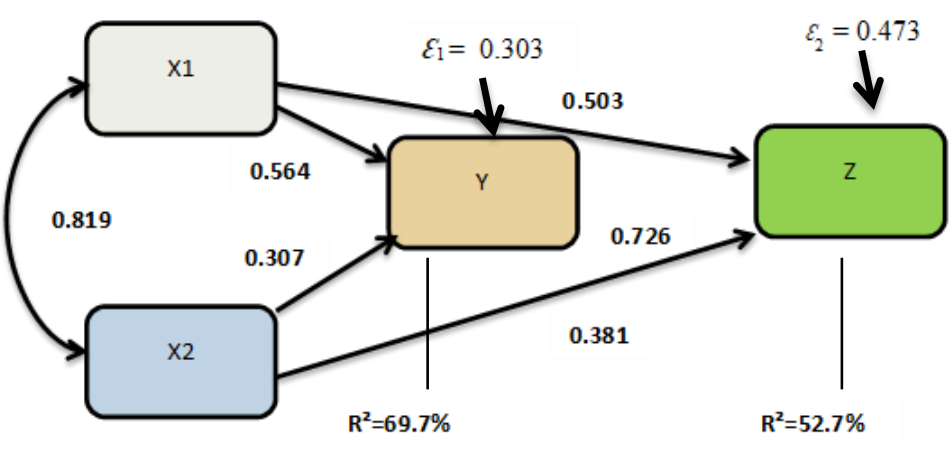

Gambar 1 : Diagram Jalur X1 dan X2 terhadap Z melalui Y Sumber: hasil olah penulis 
Tabel 2: Koefisien Jalur X1 dan X2 terhadap Y

\begin{tabular}{|c|c|c|c|c|c|c|}
\hline \multicolumn{7}{|c|}{ Coefficients $^{a}$} \\
\hline & & \multicolumn{2}{|c|}{ Unstandardized Coefficients } & \multirow{2}{*}{$\begin{array}{c}\text { Standardized } \\
\text { Coefficients } \\
\text { Beta } \\
\end{array}$} & \multirow[b]{2}{*}{$t$} & \multirow[b]{2}{*}{ Sig. } \\
\hline \multicolumn{2}{|c|}{ Model } & $B$ & Std. Error & & & \\
\hline \multirow[t]{3}{*}{1} & (Constant) & .085 & 1.038 & & .082 & .935 \\
\hline & Kepemimpinan & .360 & .078 & .564 & 4.628 & .000 \\
\hline & Lingkungan & .196 & .078 & .307 & 2.522 & .014 \\
\hline
\end{tabular}

Data Hasil diolah SPSS

Koefisien jalur kepemimpinan kepala sekolah (X1) terhadap motivasi (Y) adalah sebesar 0,564 sedangkan koefisien jalur Lingkungan kerja (X2) terhadap motivasi (Y) adalah sebesar 0,307. Nilai R square sebesar 0,697. Artinya nilai koefisien determinasi sebesar 0,697 x 100
$\%=69.7 \%$. Artinya kepemimpinan dan lingkungan kerja memberikan kontribusi untuk mempengaruhi motivasi sebesar $69.7 \%$. Sisanya sebesar $100 \%-69.7 \%=30.3 \%$ atau 0,303 dipengaruhi oleh variabel lain yang tidak diteliti dalam penelitian ini.

Tabel 3 : Koefisien Jalur X1 dan X2 Terhadap Z

\begin{tabular}{|c|c|c|c|c|c|c|}
\hline \multicolumn{7}{|c|}{ Coefficients $^{\mathrm{a}}$} \\
\hline \multirow{2}{*}{\multicolumn{2}{|c|}{ Model }} & \multicolumn{2}{|c|}{$\begin{array}{c}\text { Unstandardized } \\
\text { Coefficients } \\
\end{array}$} & \multirow{3}{*}{$\begin{array}{c}\text { Standardized } \\
\text { Coefficients }\end{array}$} & \multirow{3}{*}{$\frac{\mathrm{t}}{1.377}$} & \multirow{3}{*}{$\begin{array}{l}\text { Sig. } \\
.174\end{array}$} \\
\hline & & $\mathrm{B}$ & Std. Error & & & \\
\hline \multirow[t]{3}{*}{1} & (Constant) & 2.702 & 1.962 & & & \\
\hline & Kepemimpinan & .623 & .147 & .503 & 4.239 & .000 \\
\hline & Lingkungan & .473 & .147 & .381 & 3.211 & .002 \\
\hline
\end{tabular}

Data Hasil diolah SPSS

Koefisien jalur kepemimpinan terhadap kinerja lingkungan kerja terhadap kinerja adalah adalah sebesar 0.423 sedangkan koefisien jalur sebesar 0.381 .

Tabel 4 : Koefisien Determinasi X1, X2 dan Z

\begin{tabular}{|l|c|r|c|c|}
\hline \multicolumn{5}{|c|}{ Model Summary } \\
\hline Model & $\mathrm{R}$ & R Square & $\begin{array}{c}\text { Adjusted R } \\
\text { Square }\end{array}$ & $\begin{array}{c}\text { Std. Error of the } \\
\text { Estimate }\end{array}$ \\
\hline 1 & $.844^{\mathrm{a}}$ & .712 & .703 & 3.320790 \\
\hline \multicolumn{5}{|c|}{ Data Hasil diolah SPSS } \\
\hline
\end{tabular}

Pengaruh kepemimpinan dan lingkungan kerja secara simultan terhadap kinerja adalah sebesar $71.2 \%$ dengan nilai residu $28.8 \%$. 


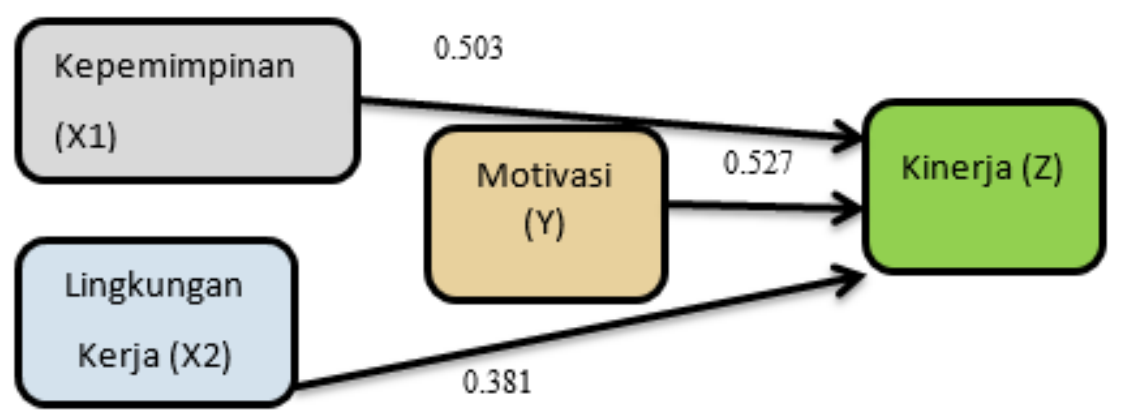

Gambar 2 : Diagram Jalur: $\mathrm{Z}=\mathbf{0 , 5 0 3 X _ { 1 } + 0 , 3 8 1 X _ { 2 } + 0 . 5 2 7 Y}$

Tabel 5 : Uji Hipotesis Secara Parsial

\begin{tabular}{|c|c|c|c|c|c|c|}
\hline \multicolumn{7}{|c|}{ Coefficients $^{a}$} \\
\hline & & \multicolumn{2}{|c|}{$\begin{array}{c}\text { Unstandardized } \\
\text { Coefficients }\end{array}$} & $\begin{array}{l}\text { Standardized } \\
\text { Coefficients }\end{array}$ & & \\
\hline \multicolumn{2}{|c|}{ Model } & $\mathrm{B}$ & Std. Error & Beta & $t$ & Sig. \\
\hline \multirow[t]{3}{*}{1} & (Constant) & .085 & 1.038 & & .082 & .935 \\
\hline & Kepemimpinan & .360 & .078 & .564 & 4.628 & .000 \\
\hline & Lingkungan & .196 & .078 & .307 & 2.522 & .014 \\
\hline
\end{tabular}

a. Dependent Variable: Motivasi

Coefficients $^{\mathrm{a}}$

\begin{tabular}{|c|c|c|c|c|c|c|}
\hline & & \multicolumn{2}{|c|}{$\begin{array}{c}\text { Unstandardized } \\
\text { Coefficients }\end{array}$} & \multirow{2}{*}{$\begin{array}{c}\text { Standardized } \\
\text { Coefficients } \\
\text { Beta }\end{array}$} & \multirow[b]{2}{*}{$\mathrm{t}$} & \multirow[b]{2}{*}{ Sig. } \\
\hline \multicolumn{2}{|c|}{ Model } & B & Std. Error & & & \\
\hline \multirow[t]{2}{*}{1} & (Constant) & 9.335 & 2.111 & & 4.421 & .000 \\
\hline & Motivasi & 1.410 & .168 & .726 & 8.377 & .000 \\
\hline
\end{tabular}

a. Dependent Variable: Kinerja

\begin{tabular}{|c|c|c|c|c|c|c|}
\hline \multicolumn{7}{|c|}{ Coefficients $^{\mathbf{a}}$} \\
\hline & & \multicolumn{2}{|c|}{$\begin{array}{c}\text { Unstandardized } \\
\text { Coefficients }\end{array}$} & $\begin{array}{l}\text { Standardized } \\
\text { Coefficients }\end{array}$ & & \\
\hline \multicolumn{2}{|c|}{ Model } & $\mathrm{B}$ & Std. Error & Beta & $\mathrm{t}$ & Sig. \\
\hline \multirow[t]{3}{*}{1} & (Constant) & 2.702 & 1.962 & & 1.377 & .174 \\
\hline & Kepemimpinan & .623 & .147 & .503 & 4.239 & .000 \\
\hline & Lingkungan & .473 & .147 & .381 & 3.211 & .002 \\
\hline
\end{tabular}

a. Dependent Variable: Kinerja 
Tabel 6 : Uji Hipotesis Secara Simultan

\begin{tabular}{|c|c|c|c|c|c|c|}
\hline \multicolumn{7}{|c|}{ ANOVA $^{a}$} \\
\hline \multicolumn{2}{|c|}{ Model } & $\begin{array}{l}\text { Sum of } \\
\text { Squares }\end{array}$ & $d f$ & $\begin{array}{l}\text { Mean } \\
\text { Square }\end{array}$ & $\mathrm{F}$ & Sig. \\
\hline \multirow[t]{3}{*}{1} & Regression & 439.417 & 2 & 219.708 & 71.253 & $.000^{\mathrm{b}}$ \\
\hline & Residual & 191.176 & 62 & 3.083 & & \\
\hline & Total & 630.593 & 64 & & & \\
\hline
\end{tabular}

a. Dependent Variable: Motivasi

b. Predictors: (Constant), Lingkungan, Kepemimpinan

Sumber : Data yang diolah SPSS

\section{KESIMPULAN}

1. Analisis deskriptif variabel kepemimpinan kepala sekolah, lingkungan kerja, motivasi dan kinerja guru PAUD di wilayah koordinator wilayah Kecamatan Bungbulang Kabupaten Garut rata-rata berada pada kategori baik.

2. Kepemimpinan dan lingkungan kerja berpengaruh positif secara parsial atau simultan terhadap motivasi.

3. Kepemimpinan dan lingkungan kerja berpengaruh positif secara parsial dan simultan terhadap kinerja guru PAUD.

4. Terdapat pengaruh yang positif dan signifikan motivasi terhadap kinerja.

\section{DAFTAR PUSTAKA}

[1.] "Prosedur penelitian: suatu pendekatan praktik / Suharsimi Arikunto | OPAC Perpustakaan Nasional RI.," Perpusnas.go.id, 2021. [Online]. Available:

https://opac.perpusnas.go.id/DetailOpa c. aspx id=801361. [Accessed: 09Nov-2021]

[2.] "Kinerja guru profesional : instrumen pembinaan, peningkatan \& penilaian / Barnawi \& Mohammad Arifin; editor, Rose Kusumaning Ratri | OPAC Perpustakaan Nasional RI.," Perpusnas.go.id, 2012. [Online]. Available: https://opac.perpusnas.go.id/DetailOpa c. aspx ?id=852962. [Accessed: 09Nov-2021]

[3.] S. Danim, "Motivasi Kepemimpinan dan Efektivitas Kelompok / Sudarwan Danim | Perpustakaan Pascasarjana UNJ," Perpustakaan Pascasarjana UNJ, 2012, doi: 978-979-518-897-1. [Online]. Available: http://digitallib.pps.unj.ac.id/index.php $? \mathrm{p}=$ show_detail\&id=27328\&keywords $=$. [Accessed: 09-Nov-2021]

[4.] Emr. 2012. Metodologi Peneltian Pendidikan. Jakarta: Pers Rajawali.

[5.] Ori Eyal and G. Roth, "Principals' leadership and teachers' motivation : Self-determination theory analysis," ResearchGate, May-2011. [Online]. Available: https://www.researchgate.net/publicati on/254188618 Principals' leadership and_teachers'_motivation_Selfdetermination_theory_analysis. [Accessed: 09-Nov-2021]

[6.] Han, JungSoon dan Richard Lynch. 2014. The Relationship between perception of School Climate and Achievement Motivation among Korean Students inGrades 6 to 12 at a selescted International School in Bangkok, Thailand. Jurnal Internasional Universtiy Of Thailand. Vol.6 No 2 tahun 2014.

[7.] Hidayatul Riski, Rusdinal Rusdinal, and Nurhizrah Gistituti, "Kepemimpinan Kepala Sekolah di Sekolah Menengah Pertama," EDUKATIF : JURNAL 
ILMU PENDIDIKAN, vol. 3, no. 6, pp. 3531-3537, 2021, doi: 10.31004/edukatif.v3i6.944. [Online]. Available:

https://edukatif.org/index.php/edukatif /article/view/944. [Accessed: 09-Nov2021]

[8.] Indrafachrudi

Soekarto,

"BAGAIMANA MEMIMPIN

SEKOLAH yang efektif / Drs.H.R. Soekarto Indrafachurudi | Dinas Kearsipan dan Perpustakaan Kota Pematang Siantar,"Perpusnas.go.id, 2020. [Online]. Available: https://katalogdisarpuspematangsiantar .perpusnas.go.id/detailopac id=13370\&tipe=koleksi.

[Accessed: 09-Nov-2021]

[9.] Indrayogi, "PENGARUH

KOMPETENSI DAN MOTIVASI BERPRESTASI TERHADAP

KINERJA GURU PENDIDIKAN JASMANI SMP NEGERI SEKABUPATEN MAJALENGKA - UPI Repository," Upi.edu, Oct. 2013, doi: http://repository.upi.edu/5848/1/T_PO R_1004749_Title.pdf. [Online]. Available:

http://repository.upi.edu/5848/.

[Accessed: 09-Nov-2021]

[10.] M. Komunikasi et al., "MEDIA MAHARDHIKA” [Online]. Available: https://ojs.stiemahardhika.ac.id/index. php/mahardika/article/download/6/5.

[Accessed: 09-Nov-2021]

[11.] "Kinerja dan profesionalisme kepala sekolah : membangun sekolah yang bermutu / Euis Karwati, Donni Juni Priansa ; editor, Sumartini | OPAC Perpustakaan Nasional RI.," Perpusnas.go.id, 2013. [Online]. Available:

https://opac.perpusnas.go.id/DetailOpa c. $\operatorname{aspx}$ ?id=912871. [Accessed: 09Nov-2021]

[12.] "Manajemen pendidikan : konsep \& prinsip pengelolaan pendidikan / Didin Kurniadin \& Imam Machali ; editor, Meita Sandra | OPAC Perpustakaan Nasional RI.," Perpusnas.go.id, 2012. [Online]. Available: https://opac.perpusnas.go.id/DetailOpa c. $\operatorname{aspx}$ ?id=852963. [Accessed: 09Nov-2021]

[13.] "PENGARUH KEPEMIMPINAN KEPALA SEKOLAH TERHADAP MOTIVASI DAN KINERJA GURU SD SE GUGUS KARTINI KECAMATAN ADIWERNA KABUPATEN TEGAL Skripsi” [Online]. Available: http://lib.unnes.ac.id/28317/1/1401412 612.pdf 